OPEN ACCESS

Edited by: Vincenzo Neri, University of Foggia, Italy

Reviewed by:

Ulf Gunnarsson,

Umeå University, Sweden

Gaetano Di Vita

University of Palermo, Italy

Francesco Litta

Catholic University of the Sacred

Heart, Italy

*Correspondence:

Liping Weng

wengping2020415@163.com

Jie Jiang

76482628@qq.com

${ }^{\dagger}$ These authors have contributed equally to this work

Specialty section:

This article was submitted to

Visceral Surgery,

a section of the journal

Frontiers in Surgery

Received: 24 July 2020 Accepted: 15 December 2020

Published: 11 February 2021

Citation:

Ji L, Zhang Y, Xu L, Wei J, Weng L and Jiang $J$ (2021) Advances in the

Treatment of Anal Fistula: A

Mini-Review of Recent Five-Year

Clinical Studies.

Front. Surg. 7:586891.

doi: 10.3389/fsurg.2020.586891

\section{Advances in the Treatment of Anal Fistula: A Mini-Review of Recent Five-Year Clinical Studies}

\author{
Lijiang $\mathrm{Ji}^{1+}$, Yang Zhang ${ }^{2 \dagger}$, Liang $\mathrm{Xu}^{3}$, Jun Wei ${ }^{1}$, Liping Weng ${ }^{1 *}$ and Jie Jiang ${ }^{1 *}$ \\ ${ }^{1}$ Department of Anorectal Surgery, Changshu Hospital Affiliated to Nanjing University of Chinese Medicine, Changshu, \\ China, ${ }^{2}$ Colorectal Disease Center, Nanjing Hospital of Chinese Medicine Affiliated to Nanjing University of Chinese Medicine, \\ Nanjing, China, ${ }^{3}$ Department of General Surgery, Changshu Hospital Affiliated to Nanjing University of Chinese Medicine, \\ Changshu, China
}

Anal fistula, with its complicated pathogenesis, has been considered as a clinical challenge for centuries. The risk of frequent recurrence and incontinence constitutes a considerable threat in the long-term treatment of anal fistula. In this work, we narratively reviewed the scientific literature of new techniques that have been used for anal fistula treatment over the recent 5 years, objectively evaluated the pros and cons of each technique on the basis of clinical outcomes, and tried to disclose the effective strategies for anal fistula treatment. Up to date, surgery is the main method used for treating anal fistula, but there is no simple technique that can completely heal complex anal fistula. In the course of surgery treatment, the healing outcome, and the protection of anal function should be weighed comprehensively. Among the innovative techniques that have emerged in recent years, combined techniques based on drainage Seton and LIFT-plug seem to be the relatively effective therapies, but their effectiveness requires more multi-center prospective randomized controlled trials with large sample size and long-term follow-up to be validated.

\footnotetext{
Keywords: anal fistula, sphincter-sparing, Seton, ligation of the intersphincteric fistula tract, healing rate, complications, recurrence rate
}

\section{INTRODUCTION}

Anal fistula is a sequela of the abscess ulceration or incision drainage that occurs around the anus and rectum, which is manifested as the formation of abnormal channels connecting the anal canal and rectum with the skin around the anus. There are 20,000 to 25,000 newly confirmed cases in the USA each year (1). A statistical analysis based on a large population database in the UK showed that the incidence of anal fistula is 1.69 cases per 10,000 individuals (2). This was also evidenced by other relevant studies (3). Patients with anal fistula are mainly adults between 30 and 40 years old, and the incidence rate of this condition in men is higher than that in women (4). In addition to severely affecting the quality of life of patients, anal fistula has also a negative impact on the psychological state of patients who often suffer from depression or anxiety symptoms. In general, anal fistula cannot be cured without therapeutic intervention. Surgical therapy is the main method used to treat anal fistula. The best treatment criterion is to eradicate the infected lesion, ensure sufficient drainage, and promote the closure of the fistula, while minimizing damage to the anal sphincter (5). The integrity of the internal anal sphincter (IAS) and external anal sphincter (EAS) is the most important guarantee for keeping normal anal function of patients. 
Anal fistula can be divided into simple and complex types according to the degree of lesions. According to the classification standards of the American Society of Colon and Rectal Surgeons (ASCRS), the former includes low transphincteric, and intersphincteric fistulas, which account for lesser than $30 \%$ of the sphincter complex. Regarding simple anal fistula, especially distal cases, fistulotomy can be used to obtain ideal treatment results (6). However, complex anal fistula is one of the refractory diseases encountered in colorectal surgery; it is transphincteric fistula that account for more than $30 \%$ of sphincter complex, and includes anal fistulas related to malignancy, inflammatory bowel disease, radiation, chronic diarrhea, or preexisting fecal incontinence. Due to the diverse causes and forms of complex anal fistula, its treatments are often accompanied by a high risk of recurrence and potential incontinence disorders, and there still is a lack of clinical consensus on the best surgical approach. Cutting Seton is a preliminary exploration of sphincter-sparing technology. It works on the principle that gradual detachment of muscles will lead to fibrosis and necrosis, which can maintain the integrity of the sphincter complex with minimal damage to the cutting end (5). Nevertheless, studies have shown that cutting Seton does not sufficiently protect the anal sphincter $(7,8)$, and the postoperative anal incontinence rate was even as high as $63 \%$ (9). The slow section of the sphincters by cutting Seton produces a sphincter injury, with outcomes perhaps even less controllable than a simple lay-open fistulotomy. Total sphincter preservation surgery has gradually become the first choice for anal fistula treatment. In the past few decades, several sphincter-sparing techniques have been established, including endorectal advancement flap (ERAF), ligation of the intersphincteric fistula tract (LIFT), fibrin glue, anal fistula plug, fistula laser closure, video-assisted anal fistula treatment (VAAFT), and adipose-derived stem cells; the last review of these studies was published in 2015 (10). Based on these independent sphincter-sparing techniques, to further diminish the recurrence rate, protect the anal sphincter and obtain better postoperative outcomes, some innovative, combined, and modified new therapies have been proposed and applied in clinical studies in recent years. However, due to the diversity of treatment methods and the inevitable heterogeneity of clinical trials, their variable outcomes are prone to generate confusion and misunderstanding.

Therefore, this review aimed to systematically summarize the new anal fistula therapies that have been applied in clinics in the past 5 years, and critically evaluate these methods from the perspective of healing rate, complication, and recurrence rate in order to assess the feasibility of these anal fistula treatment techniques.

\section{METHODOLOGY}

A mini-review of the last 5-year (January 2015 to September 2020) studies focused on the treatment of anal fistula was performed using papers obtained from electronic databases, including PubMed, Web of science, Embase, and Cochrane library. The search was restricted to articles published in English language and the search terms included "anal fistula," "fistulain-ano," "treatment," and "sphincter-sparing." Finally, 29 papers were selected, which included 21 prospective cohort studies (1131 ), seven retrospective cohort studies (32-37), and one case report (38).

\section{Advanced Techniques Modified Seton}

Taking into account the insufficient anal sphincter protection during the treatment of anal fistula by cutting Seton, a preliminary improvement method of drainage Seton (loose Seton) was proposed, which forms continuous drainage of the fistula through medical thread, rubber band, and other materials to prevent the formation of abscess. Although the drainage Seton completely preserves the sphincter and reduces anal incontinence, previous study results showed that the longterm recurrence rate for complex anal fistula treatment was up to $20-80 \%(39,40)$. Haennig et al. (12) performed a prospective observational cohort study involving 81 patients with Crohn's disease-induced perianal fistula to evaluate the treatment effectiveness of drainage Seton combined with infliximab. It was found that fistulas in $72.5 \%$ of patients were closed, $13.6 \%$ of patients had acute adverse events related to anti$\mathrm{TNF} \alpha$ therapy, and the recurrence rate was $45.8 \%$ after a longterm follow-up (Table 1). Among them, gender, rectum-vaginal, anal stenosis, and complex fistula were considered to be the association factors of treatment failure. Izadpanah et al. (16) introduced another combination therapy called pulling Seton based on Seton technique, which combined non-cutting and cutting mechanisms. As listed in the Table 1, this prospective study showed that $94 \%$ of 201 patients with high anal fistula were healed, and the incontinence rate and recurrence rate were controlled within a small and acceptable range $(<5 \%)$ (16). In addition, the concept of rerouting of the fistula tract was first proposed by Mann and Clifton (41). This technique can effectively treat anorectal fistula and high anal fistula by relocating the fistula of the sphincteric external part to the position between the sphincter and immediately repairing the EAS. Omar et al. (28) implemented a prospective randomized controlled trial to compare the clinical outcomes between the separate drainage Seton and drainage Seton combined with fistula tract rerouting (EAS-sparing Seton after rerouting) and their results showed that there was no significant difference in the recurrence rate and complications between the two groups, but the combined technique reduced the postoperative healing time and the number of patients who required secondary fistulotomy. Abdelnaby et al. (24) further combined the drainage Seton, fistula tract rerouting, and mucosal advancement flap. They found that this triple therapy could significantly reduce fecal incontinence, but it took more time for surgery and recovery when compared with the method of rerouting Seton around the IAS. In short, after gradual improvement, Seton-based techniques such as pulling Seton, EAS-sparing Seton after rerouting, and rerouting Seton around the EAS combined with mucosal advancement flap have become more efficient methods for high anal fistula treatment compared to the conventional seton method. 
TABLE 1 | Published articles on new techniques of modified Seton for anal fistula treatment in the past 5 years.

\begin{tabular}{|c|c|c|c|c|c|c|c|}
\hline Studies & Type of study & $\begin{array}{l}\text { Advanced } \\
\text { techniques }\end{array}$ & No. patients & Follow-up (week) & Healing rate (\%) & $\begin{array}{c}\text { Complications } \\
(\%)\end{array}$ & $\begin{array}{c}\text { Recurrence } \\
\text { rate }(\%)\end{array}$ \\
\hline $\begin{array}{l}\text { Abdelnaby } \\
\text { et al. (24) }\end{array}$ & $\begin{array}{l}\text { Prospective } \\
\text { randomized controlled } \\
\text { study }\end{array}$ & $\begin{array}{l}\text { Rerouting Seton } \\
\text { around the EAS } \\
\text { combined with } \\
\text { mucosal advancement } \\
\text { flap }\end{array}$ & 49 & $82.8 \pm 17.2$ & 95.9 & 8.2 & 4.1 \\
\hline $\begin{array}{l}\text { Haennig et al. } \\
\text { (12) }\end{array}$ & $\begin{array}{l}\text { Prospective } \\
\text { observational cohort } \\
\text { study }\end{array}$ & $\begin{array}{l}\text { Drainage Seton } \\
\text { combined with } \\
\text { anti-TNF } \alpha \text { therapy }\end{array}$ & 81 & $256(8-1,052)$ & 72.5 & 13.6 & 45.8 \\
\hline $\begin{array}{l}\text { Izadpanah } \\
\text { et al. (16) }\end{array}$ & $\begin{array}{l}\text { Prospective } \\
\text { observational cohort } \\
\text { study }\end{array}$ & Pulling Seton & 201 & 264 (96-384) & 94.0 & 3.0 & 4.5 \\
\hline
\end{tabular}

IAS, internal anal sphincter; EAS, external anal sphincter.

\section{Modified LIFT}

LIFT is an effective and low-cost sphincter-sparing technique which was first introduced by Rojanasakul et al. (42), with a success rate of $94.4 \%$ and the absence of continence failures (42). LIFT technique mainly ligates and cuts the fistula between the sphincters, scrapes the infected tissue of the fistula wall, and tightens the fistula tract with ligation, which can effectively avoid repeated infections caused by fecal particles. It is appropriate for transsphincteric fistulas that have well-formed fistulas including most complex anal fistulas (43), recurrent anal fistula (44), and fistulas that fail after other surgical procedures, but not for early fistulas without clearly formed fistula. Additionally, another limitation of LIFT is that the healing outcome is unstable; some previous studies have shown that the success rate is only about 50\% (44, 45). Emile et al. (46) suggested that Crohn's disease, horseshoe fistulas, and previous fistula surgery are predictors of LIFT failure. A report published in 2013 tracked the long-term results after LIFT treatment, and concluded that long anal tracts were a part of the many postoperative failures (47). To improve the healing rate of LIFT technique, "medialization of the external opening to the intersphincteric wound" was suggested as one of the corrective measures in LIFT failure cases (48). Wright et al. (49) indicated that the placement of Seton followed by fistulotomy and rectal advancement flap could treat $50 \%$ of the patients with LIFT failures.

In recent years, LIFT technique has gained in popularity worldwide; some improved techniques based on LIFT have also been proposed. For instance, Arroyo et al. (19) improved the LIFT technique and proved that ligation of the intersphincteric fistula, but not excision, was safe and effective for treating anal fistula via a prospective observational trial (Table 2). Another modified LIFT technique was carried out by Kang et al. (23), who performed LIFT by lateral approach which cuts along the fistula from the external opening until the sphincter space is exposed, and ligation is undertaken near the internal anal sphincter followed by the removal of the ligated distal part. However, the above two methods have relatively high recurrence rates, 21 and 18\%, respectively (Table 2). In 2016, a multi-center prospective randomized trial demonstrated that when compared to the simple LIFT technique, the LIFT-plug method, which is an improved LIFT procedure by addition of a bioprosthetic anal fistula plug, increased the healing rate from 83.9 to $94 \%$ and shortened the time required for healing (15). Similarly, Zhao et al. (35) found LIFT-plug procedure as a convenient method for treating transsphincteric perianal fistulas via a long-term retrospective cohort study (Table 2). Their results showed that LIFT-plug procedure led to a high healing rate, low trauma, and effective protection of anal sphincter. Another modification in LIFT procedure proposed by Zwiep et al. (37) recommended placing a "biological mesh" on the plane between the sphincters (BioLIFT). This retrospective cohort study showed that the success rate and safety of this technique was reasonable, but the cost factor was one of its limitations (37). Based on these studies, we concluded that LIFT-plug and BioLIFT were two alternative solutions for the treatment of transsphincteric anal fistula. However, the improved advantages of these new techniques need more prospective studies for further confirmation.

\section{OTSC $^{\circledR}$ (Over-the-Scope-Clip) Proctology Device}

OTSC $^{\circledR}$ proctology device is a system of elastic nitinol alloy closure clip, and is used to close the fistula tract from inside by placing the device on the internal opening of fistula. Prosst et al. (50) first applied the experience of gastrointestinal endoscopy to the treatment of anal fistula by modifying the proctology clip in 2012. Recently, a 3-year long-term retrospective study 
showed that the fistula tracts were completely closed in 59\% of 22 patients with anal fistula (51). Similarly, the results of a retrospective cohort study which enrolled 10 patients treated with the OTSC ${ }^{\circledR}$ proctology device indicated that the nitinol closure clip had to be removed from one patient due to persistent anal pain; three of nine recovered patients had relapsed during a short-term follow-up, and all patients had no complication of postoperative fecal incontinence (32). In addition, a prospective randomized controlled study carried out by Mascagni et al. (27) showed that $93.3 \%$ of 15 anal fistula patients treated with OTSC ${ }^{\circledR}$ proctology device were healed (Table 3 ), and the clinical outcomes of OTSC ${ }^{\circledR}$ proctology device treatment were better than those of fistulectomy and primary sphincteroplasty (FIPS; described below) in many aspects, including the postoperative pain, anal sphincter protection, recovery time, and length of hospital stay. As shown in Table 3, although the procedure was characterized by tolerability and minimal invasiveness, the success rate of OTSC clip fluctuated and the recurrence rate was high in the two retrospective analyses of small sample sizes $(32,51)$. Therefore, the effectiveness of OTSC ${ }^{\circledR}$ proctology device needs additional validation with a large-scale prospective randomized trial.

\section{FIPS}

Even though fistulotomy is still the preferred technique for simple anal fistula treatment, high incontinence rate and keyhole deformity are the two main drawbacks of the traditional fistulotomy. The sphincter-sparing method has been widely recognized in the recent decades, but the high recurrence rate remains an important challenge for colorectal surgeons. In fact, as early as 1985, Parkash et al. (52) proposed an immediate sphincter repair technique to improve fistulotomy, namely FIPS. Compared with the conventional fistulotomy, FIPS reduces the risk of postoperative keyhole deformity and fecal incontinence. Moreover, compared with the majority of sphincter preservation techniques, FIPS decreases the recurrence rate after surgery. Therefore, this compromised method has received new attention in recent years (Table 4).

A retrospective clinical trial designed by De Hous et al. (36) proved that FIPS could avoid the formation of keyhole

TABLE 2 | Published articles on new techniques of modified LIFT for anal fistula treatment in the past 5 years.

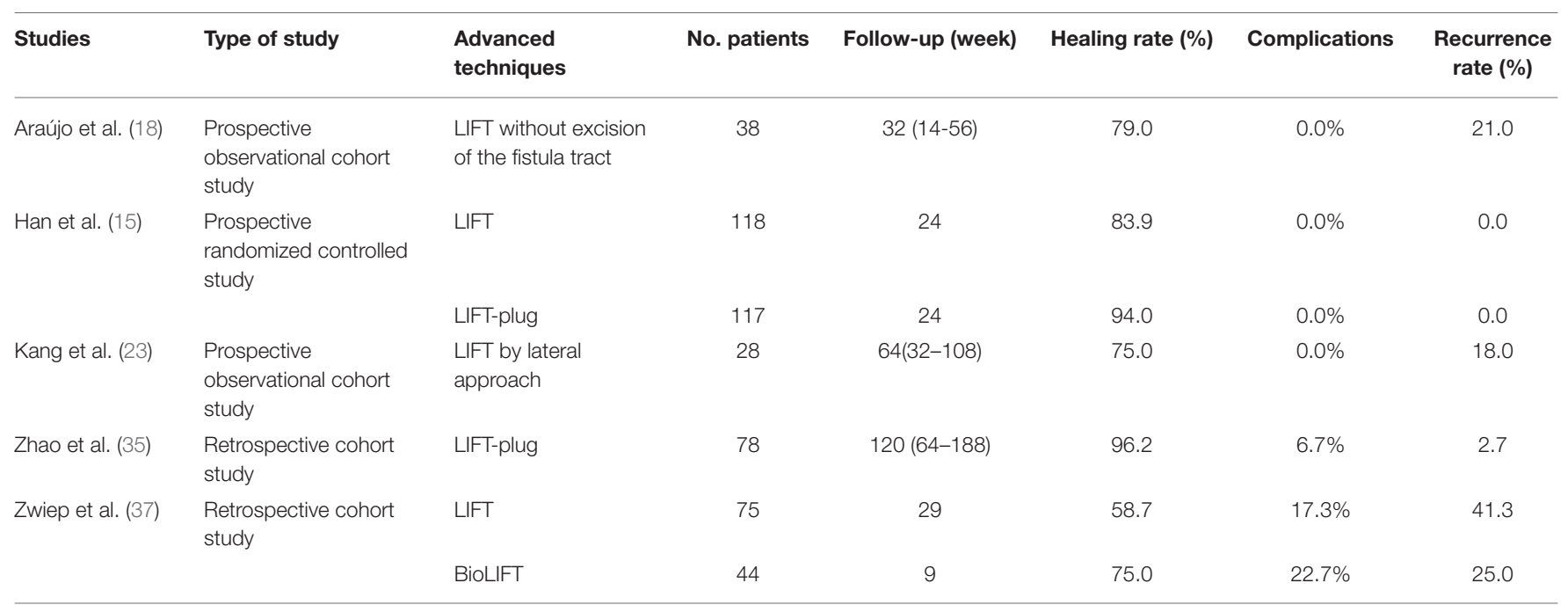

LIFT, ligation of the intersphincteric fistula tract.

TABLE 3 | Published articles on new techniques of OTSC ${ }^{\circledR}$ proctology device for anal fistula treatment in the past 5 years.

\begin{tabular}{|c|c|c|c|c|c|c|c|}
\hline Studies & Type of study & $\begin{array}{l}\text { Advanced } \\
\text { techniques }\end{array}$ & No. patients & Follow-up (week) & Healing rate $(\%)$ & Complications & $\begin{array}{c}\text { Recurrence } \\
\text { rate }(\%)\end{array}$ \\
\hline Dango et al. (51) & $\begin{array}{l}\text { Retrospective cohort } \\
\text { study }\end{array}$ & $\begin{array}{l}\text { OTSC }^{\circledR} \text { proctology } \\
\text { device }\end{array}$ & 22 & $144(76-192)$ & 59.0 & $0.0 \%$ & 41.0 \\
\hline $\begin{array}{l}\text { Marinello et al. } \\
\text { (32) }\end{array}$ & $\begin{array}{l}\text { Retrospective cohort } \\
\text { study }\end{array}$ & $\begin{array}{l}\text { OTSC }^{\circledR} \text { proctology } \\
\text { device }\end{array}$ & 10 & $60(24-104)$ & 60.0 & $0.0 \%$ & 33.3 \\
\hline $\begin{array}{l}\text { Mascagni et al. } \\
\text { (27) }\end{array}$ & $\begin{array}{l}\text { Prospective } \\
\text { randomized controlled } \\
\text { study }\end{array}$ & $\begin{array}{l}\text { OTSC }^{\circledR} \text { proctology } \\
\text { device }\end{array}$ & 15 & 144 & 93.3 & $0.0 \%$ & 6.7 \\
\hline
\end{tabular}

OTSC, over the scope clip. 
deformity in the treatment of patients with simple anal fistula and pointed out that the occurrence of keyhole deformity was positively correlated with posterior fistula. Besides, the postoperative recurrence rate of FIPS was within an acceptable range (4.2\%). In addition, the retrospective evaluation of Seyfried et al. (33) found that primary sphincter reconstruction not only had satisfactory effects on the distal fistula, but also an effective treatment for intermediate fistula, and even led to comparable clinical outcomes in the treatment of proximal fistula. However, the therapeutic effect of this technique decreased with the complexity of anal fistula. Litta et al. (34) also confirmed that patients with complex or transsphincteric anal fistula had lower postoperative satisfaction with FIPS. From these findings, it was revealed that FIPS is a simple, efficient, and low-recurrence anal fistula therapy, especially for simple anal fistula, but the potential risk of incontinence and keyhole deformity after surgery should be informed to patients before surgery.

\section{Filling Therapy}

In recent years, some derivative methods based on anal fistula plug and fibrin glue have also been proposed and developed. These methods are mainly improved by optimizing the synthetic material of the implanted fistula plug (Table 5). For example, Bobkiewicz et al. (38) introduced a new technique to treat anal fistula by establishing a novel biomaterial model for making anal fistula plug. They found that the plug made from acellular dermal matrix could fuse with the tissue and proliferate excessively in the fistula. Additionally, the operation process was simple, and the operation time and postoperative recovery time were short. However, this study was a case report and lacked long-term clinical trial verification with a large sample size. Similarly, other filling matrices, including platelet-rich plasma (PRP), autologous cartilage, fat, autologous micro-fragmented adipose tissue, and allogeneic bone marrow-derived mesenchymal stromal cells (MSCs), have also been reported for the treatment of anal fistula. In their work, de la Portilla et al. (25) implemented a prospective double-blind randomized trial to compare the effectiveness of autologous PRP and fibrin glue in cryptogenic anal fistula treatment. The results showed that the therapeutic effects of these two techniques were equivalent and there was no incontinence-related adverse events, but their recurrence rates were high, 33.3 and $31.3 \%$, respectively (Table 5). Ozturk (14) used autologous cartilage as a raw material for anal fistula plug. A 2-year follow-up revealed that the fistula tracts in $90 \%$ of the 10 patients were closed after surgery, and there were no short-term complications, but two of the recovered patients relapsed in the long-term follow-up. Recently, autologous fat tissues have been considered as safe, effective, and feasible biomaterials in the treatments of anal fistula. Stroumza et al. (22) evaluated the efficacy of fat transplantation in the treatment of anal fistula through a prospective observational trial. The results showed that $73 \%$ of patients recovered completely within 6-month follow-up without any side effect (Table 5). A similar prospective clinical trial designed by Laureti et al. (30) proved that autologous micro-fragmented adipose tissue injection allowed the recovery of $66.7 \%$ of patients after surgery, and there was no complication recorded. Moreover, through a prospective double-blind placebo-controlled trial, Molendijk et al. (13) found that bone MSCs from healthy donors can effectively treat perianal fistula induced by Crohn's disease compared with placebo treatment, and the efficacy was related to the cell density of bone MSCs; the effect was best when the cell concentration was $3 \times 10^{7}$ (Table 5). Furthermore, Ratto et al. (17) initially explored the effectiveness of Curaseal $\mathrm{AF}^{\mathrm{TM}}$ device in anal fistula treatment through a short-term (6 months) clinical trial; their results indicated that the technique was simple, effective, and did not increase the risk of postoperative incontinence, but these preliminary results require further validation by more clinical trials with longer follow-up and larger sample size. In summary, these multivariate filling matrices made of biomaterials are feasible therapies for anal fistula treatment. The common advantages of their clinical outcomes are the complete preservation of the anal sphincter and zero side effect. The primary disadvantage is that the recurrence rate is relatively high, especially for the long-term recurrence rate.

\section{Photodynamic Therapy (PDT)}

In 2017, Arroyo et al. (19) first introduced the PDT to the anal fistula treatment. PDT is a treatment that combines light energy and photosensitizers to induce photooxidative damage to target

TABLE 4 | Published articles on new techniques of FIPS for anal fistula treatment in the past 5 years.

\begin{tabular}{|c|c|c|c|c|c|c|c|}
\hline Studies & Type of study & $\begin{array}{l}\text { Advanced } \\
\text { techniques }\end{array}$ & No. patients & Follow-up (week) & Healing rate (\%) & Complications & $\begin{array}{l}\text { Recurrence } \\
\text { rate (\%) }\end{array}$ \\
\hline De et al. (36) & $\begin{array}{l}\text { Retrospective cohort } \\
\text { study }\end{array}$ & FIPS & 24 & $12(8-25.2)$ & 95.8 & $25.0 \%$ & 4.2 \\
\hline Litta et al. (34) & $\begin{array}{l}\text { Retrospective cohort } \\
\text { study }\end{array}$ & FIPS & 203 & $224 \pm 124$ & 93.0 & $13.0 \%$ & 8.0 \\
\hline $\begin{array}{l}\text { Mascagni et al. } \\
\text { (27) }\end{array}$ & $\begin{array}{l}\text { Prospective } \\
\text { randomized controlled } \\
\text { study }\end{array}$ & FIPS & 15 & 144 & 100.0 & $0.0 \%$ & 0.0 \\
\hline Seyfried et al. (33) & $\begin{array}{l}\text { Retrospective cohort } \\
\text { study }\end{array}$ & FIPS & 424 & $44(28-800)$ & 88.2 & $23.0 \%$ & 4.2 \\
\hline
\end{tabular}

FIPS, fistulectomy and primary sphincteroplasty. 
tissues or cells. It has been mainly used in cancer treatment before. Through two long-term prospective observational trials, Arroyo et al. (19) and Arroyo et al. (29) showed that PDT was an effective sphincter-sparing therapy with a simple surgical procedure, high safety, and healing rate ranging from 65.3 to $80 \%$ (Table 6), which can be considered as an alternative choice for patients with complex anal fistula. However, to date, clinical research related to PDT is still very limited, and the cost of this technique is higher than that of traditional surgery; thus, practitioners need to carefully evaluate its cost-effectiveness when choosing treatment options.

\section{Other Surgical Procedures}

In addition to the six types of treatments described above, as listed in the Table 7, some other surgical treatments for anal fistulas such as proximal superficial cauterization, emptying regularly fistula tracts and curettage of tracts (PERFACT) procedure, transanal opening of intersphincteric space (TROPIS), and tunnel-like fistulectomy plus draining Seton combined with incision of internal opening of anal fistula (TFSIA) have also been proposed. In 2015, a new procedure called PERFACT for high complex anal fistula treatment was proposed. The key of this technique is to cauterize the mucosal

TABLE 5 | Published articles on new techniques of filling therapy for anal fistula treatment in the past 5 years.

\begin{tabular}{|c|c|c|c|c|c|c|c|}
\hline Studies & Type of study & $\begin{array}{l}\text { Advanced } \\
\text { techniques }\end{array}$ & No. patients & Follow-up (week) & Healing rate (\%) & $\begin{array}{c}\text { Complications } \\
(\%)\end{array}$ & $\begin{array}{c}\text { Recurrence } \\
\text { rate }(\%)\end{array}$ \\
\hline $\begin{array}{l}\text { Bobkiewicz et al. } \\
\text { (38) }\end{array}$ & Case report & $\begin{array}{l}\text { Acellular dermal } \\
\text { matrix plug }\end{array}$ & 1 & 8 & 100.0 & 0.0 & 0.0 \\
\hline de et al. (25) & $\begin{array}{l}\text { Prospective } \\
\text { randomized controlled } \\
\text { study }\end{array}$ & PRP & 32 & 48 & 71.0 & 0.0 & 33.3 \\
\hline $\begin{array}{l}\text { Stroumza et al. } \\
\text { (22) }\end{array}$ & $\begin{array}{l}\text { Prospective } \\
\text { observational cohort } \\
\text { study }\end{array}$ & $\begin{array}{l}\text { Fat GRAFT } \\
\text { technique }\end{array}$ & 11 & 24 & 73.0 & 0.0 & 27.0 \\
\hline \multirow{3}{*}{$\begin{array}{l}\text { Molendijk et al. } \\
\text { (13) }\end{array}$} & & $\begin{array}{l}\text { Allogeneic bone } \\
\text { MSCs } 3 \times 10^{7}\end{array}$ & 5 & 24 & 80.0 & 0.0 & 0.0 \\
\hline & & $\begin{array}{l}\text { Allogeneic bone } \\
\text { MSCs } 9 \times 10^{7}\end{array}$ & 5 & 24 & 20.0 & 0.0 & 0.0 \\
\hline & & Placebo & 6 & 24 & 33.3 & 0.0 & 50.0 \\
\hline Ratto et al. (17) & $\begin{array}{l}\text { Prospective } \\
\text { observational cohort } \\
\text { study }\end{array}$ & $\begin{array}{l}\text { Curaseal AF }{ }^{T M} \\
\text { device }\end{array}$ & 10 & 24 & 70.0 & 0.0 & 30.0 \\
\hline
\end{tabular}

PRP, platelet-rich plasma; GRAFT, grafting in anal fistula treatment; MSCs, marrow-derived mesenchymal stromal cells.

TABLE 6 | Published articles on new techniques of PTD for anal fistula treatment in the past 5 years.

\begin{tabular}{|c|c|c|c|c|c|c|c|}
\hline Studies & Type of study & $\begin{array}{l}\text { Advanced } \\
\text { techniques }\end{array}$ & No. patients & Follow-up (week) & Healing rate $(\%)$ & $\begin{array}{c}\text { Complications } \\
(\%)\end{array}$ & $\begin{array}{c}\text { Recurrence } \\
\text { rate (\%) }\end{array}$ \\
\hline Arroyo et al. (19) & $\begin{array}{l}\text { Prospective } \\
\text { observational cohort } \\
\text { study }\end{array}$ & PDT & 10 & $59.6(48-80)$ & 80.0 & 0.0 & 20.0 \\
\hline Arroyo et al. (29) & $\begin{array}{l}\text { Prospective } \\
\text { observational cohort } \\
\text { study }\end{array}$ & PDT & 49 & 48 & 65.3 & 6.3 & 34.7 \\
\hline
\end{tabular}

PDT, photodynamic therapy. 
surfaces located around the internal opening of the fistula, and to preserve the tracts (fistulas, branches, and cavities) clean (11). Their prospective cohort trial proved that $79.5 \%$ of the patients were effectively treated and there was no case of surgery-induced incontinence being recorded (Table 7). Two years later, the same authors reported another new technique for the same disease, called TROPIS (20). The results showed that TROPIS technique increased the healing rate to $84.5 \%$, and the overall healing rate exceeded $90 \%$. In addition, a prospective randomized controlled trial conducted by Yan and $\mathrm{Ma}$ (31) found that although the clinical outcomes of TFSIA and cutting Seton did not differ between the healing rate and the recurrence rate, the former significantly reduced the postoperative recovery time, keyhole deformity rate, and incontinence score.

\section{Non-surgical Procedures}

Since 2015, some non-surgical methods for the treatment of anal fistula have gradually emerged as well, but the functions of these methods are often limited and even ineffective, and they are not satisfactory alternative methods for anal fistula surgery (Table 8). For instance, Iqbal et al. (26) proposed a nonsurgical therapy for the treatment of low perianal fistula by washing fistula with $1 \%$ silver nitrate solution. Their prospective observational trial proved that silver nitrate successfully healed $76.3 \%$ of patients with low perianal fistula, indicating that this simple, easily realized, and side-effect-free therapy was feasible for the treatment of low perianal fistula (Table 8). Additionally, a previous study tried to use ozone to treat chronic anal fistula (21). Although the treatment did not have any side effect or complication induced by ozone injection, the cure rate was only $25 \%$ among the 12 patients who participated in the prospective clinical trial, and one third of the recovered patient relapsed, so this technique has not yet been conventionally recognized.

\section{CONCLUSION}

With the increasing attention being paid to anorectal diseases and the continuous advancement of science and technology, a large number of new therapies have emerged to address the issue of complex anal fistula. Due to the characteristics of multiple inducements and forms of complex anal fistula, there is a lack of unified criteria for the efficacy evaluation of various anal fistula treatment methods, and no consensus has been reached on the best therapy. The specific implementation of a given treatment often has to formulate personalized schemes according to the actual situation of the patient. There is no simple technique that can completely heal complex anal fistulas. The effectiveness of surgery and the protection of anal function must be considered comprehensively during the treatment. As far as the current research results are concerned, several combined

TABLE 7 | Published articles on new techniques of other surgical procedures for anal fistula treatment in the past 5 years.

\begin{tabular}{|c|c|c|c|c|c|c|c|}
\hline Studies & Type of study & $\begin{array}{l}\text { Advanced } \\
\text { techniques }\end{array}$ & No. patients & Follow-up (week) & Healing rate $(\%)$ & Complications & $\begin{array}{c}\text { Recurrence } \\
\text { rate (\%) }\end{array}$ \\
\hline $\begin{array}{l}\text { Garg and Garg } \\
\text { (11) }\end{array}$ & $\begin{array}{l}\text { Prospective } \\
\text { observational cohort } \\
\text { study }\end{array}$ & $\begin{array}{l}\text { PERFACT } \\
\text { procedure }\end{array}$ & 44 & $36(20-56)$ & 79.5 & $9.1 \%$ & 20.5 \\
\hline Garg (20) & $\begin{array}{l}\text { Prospective } \\
\text { observational cohort } \\
\text { study }\end{array}$ & TROPIS & 52 & $36(24-84)$ & 84.6 & $1.9 \%$ & 15.4 \\
\hline Yan and Ma (31) & & Cutting Seton & 40 & 24 & 85.0 & $1.2 \pm 0.7^{\#}$ & 15.0 \\
\hline
\end{tabular}

PERFACT, proximal superficial cauterization, emptying regularly fistula tracts, and curettage of tracts; TROPIS, transanal opening of intersphincteric space; TFSIA, tunnel-like fistulectomy plus draining Seton combined with incision of internal opening of anal fistula; \#Wexner anal incontinence score after 6 months of operation.

TABLE 8 | Published articles on new techniques of non-surgical procedures for anal fistula treatment in the past 5 years.

\begin{tabular}{|c|c|c|c|c|c|c|c|}
\hline Studies & Type of study & $\begin{array}{l}\text { Advanced } \\
\text { techniques }\end{array}$ & No. patients & Follow-up (week) & Healing rate (\%) & $\begin{array}{c}\text { Complications } \\
(\%)\end{array}$ & $\begin{array}{c}\text { Recurrence } \\
\text { rate (\%) }\end{array}$ \\
\hline lqbal et al. (26) & $\begin{array}{l}\text { Prospective } \\
\text { observational cohort } \\
\text { study }\end{array}$ & $\begin{array}{l}1 \% \text { silver } \\
\text { nitrate }\end{array}$ & 76 & 10 & 76.3 & 0.0 & 23.7 \\
\hline Ozturk et al. (21) & $\begin{array}{l}\text { Prospective } \\
\text { observational cohort } \\
\text { study }\end{array}$ & Ozone & 12 & 48 & 25.0 & 0.0 & 33.3 \\
\hline
\end{tabular}


techniques based on drainage Seton (pulling Seton, EAS-sparing Seton after rerouting, and rerouting Seton around the EAS combined with mucosal advancement flap) and LIFT-plug are considered to be the feasible therapies of complex anal fistulas, but their clinical outcomes need more prospective randomized controlled trials with multi-center, large sample size, and longterm follow-up for credible confirmation. Additionally, due to the limited data available, which unfortunately is the nature of this research field, it is difficult to make reliable judgments about these technologies. So far, none of these treatment techniques have, however, added a paradigm shift in success rate when evaluated in larger and better controlled studies. In the future, a large number of high-quality clinical trials are urgently needed to jointly answer the question of the best strategy for anal fistula treatment.

\section{REFERENCES}

1. Nelson R. Anorectal abscess fistula: what do we know? Surg Clin North Am. (2002) 82:1139-51, v-vi. doi: 10.1016/S0039-6109(02)00063-4

2. García-Olmo D, Van Assche G, Tagarro I, Diez MC, Richard MP, Khalid JM, et al. Prevalence of anal fistulas in Europe: systematic literature reviews and population-based database analysis. Adv Ther. (2019) 36:3503-18. doi: 10.1007/s12325-019-01117-y

3. Hokkanen SR, Boxall N, Khalid JM, Bennett D, Patel H. Prevalence of anal fistula in the United Kingdom. World J Clin Cases. (2019) 7:1795-804. doi: 10.12998/wjcc.v7.i14.1795

4. Yamana T. Japanese practice guidelines for anal disorders II. Anal fistula J Anus Rectum Colon. (2018) 2:103-9. doi: 10.23922/jarc.2018-009

5. Bleier JI, Moloo H. Current management of cryptoglandular fistula-in-ano. World J Gastroenterol. (2011) 17:3286-91. doi: 10.3748/wjg.v17.i28.3286

6. Alasari S, Kim NK. Overview of anal fistula and systematic review of ligation of the intersphincteric fistula tract (LIFT). Tech Coloproctol. (2014) 18:13-22. doi: 10.1007/s10151-013-1050-7

7. Patton V, Chen CM, Lubowski D. Long-term results of the cutting seton for high anal fistula. ANZ J Surg. (2015) 85:720-7. doi: 10.1111/ans.13156

8. Raslan SM, Aladwani M, Alsanea N. Evaluation of the cutting seton as a method of treatment for perianal fistula. Ann Saudi Med. (2016) 36:210-5. doi: 10.5144/0256-4947.2016.210

9. Hämäläinen, K. P., and Sainio, A. P. (1997). Cutting seton for anal fistulas: high risk of minor control defects. Dis Colon Rectum. 40:1443-6; discussion 1447. doi: 10.1007/BF02070710

10. Limura E, Giordano P. Modern management of anal fistula. World J Gastroenterol. (2015) 21:12-20. doi: 10.3748/wjg.v21.i1.12

11. Garg P, Garg M. PERFACT procedure: a new concept to treat highly complex anal fistula. World J Gastroenterol. (2015) 21:4020-9. doi: 10.3748/wjg.v21.i13.4020

12. Haennig A, Staumont G, Lepage B, Faure P, Alric L, Buscail L, et al. The results of seton drainage combined with anti-TNF $\alpha$ therapy for anal fistula in Crohn's disease. Colorectal Dis. (2015) 17:311-9. doi: 10.1111/codi.12851

13. Molendijk, I., Bonsing, B. A., Roelofs, H., Peeters, K. C., Wasser, M. N., Dijkstra, G., et al. (2015). Allogeneic bone marrow-derived mesenchymal stromal cells promote healing of refractory perianal fistulas in patients with Crohn's disease. Gastroenterology. 149:918-927.e916. doi: 10.1053/j.gastro.2015.06.014

14. Ozturk E. Treatment of recurrent anal fistula using an autologous cartilage plug: a pilot study. Tech Coloproctol. (2015) 19:301-7. doi: 10.1007/s10151-015-1299-0

15. Han JG, Wang ZJ, Zheng Y, Chen CW, Wang XQ, Che XM, et al. Ligation of intersphincteric fistula tract vs ligation of the intersphincteric fistula tract plus a bioprosthetic anal fistula plug procedure in patients with transsphincteric anal fistula: early results of a multicenter prospective randomized trial. Ann Surg. (2016) 264:917-22. doi: 10.1097/SLA.0000000000001562

\section{AUTHOR CONTRIBUTIONS}

LJ, YZ, LX, JW, LW, and JJ contributed in drafting the manuscript. LW conceptualized and designed the work. All authors contributed to the article and approved the submitted version.

\section{FUNDING}

This work was supported by the Changshu Health and Family Planning Commission Supporting Project (CSWS201514), the Suzhou Municipal Science and Technology Bureau Supporting Project (SYSD2016015, SYSD2019004, SYSD2019195), and the Changshu Municipal Science and Technology Bureau Supporting Project (CS201623).

16. Izadpanah A, Rezazadehkermani M, Hosseiniasl SM, Farghadin A, Ghahramani L, Bananzadeh A, et al. Pulling Seton: combination of mechanisms. Adv Biomed Res. (2016) 5:68. doi: 10.4103/2277-9175.180637

17. Ratto C, Litta F, Donisi L, Parello A. Prospective evaluation of a new device for the treatment of anal fistulas. World J Gastroenterol. (2016) 22:6936-43. doi: 10.3748/wjg.v22.i30.6936

18. Araújo SEA, Marcante MT, Mendes CRS, Bertoncini AB, Seid VE, Horcel LA, et al. Interesfincterial ligation of fistula tract (LIFT) for patients with anal fistulas: a Brazilian bi-institutional experience. Arq Bras Cir Dig. (2017) 30:235-8. doi: 10.1590/0102-6720201700040002

19. Arroyo A, Moya P, Rodríguez-Prieto MA, Alcaide MJ, Aguilar MM, Bellón M, et al. Photodynamic therapy for the treatment of complex anal fistula. Tech Coloproctol. (2017) 21:149-53. doi: 10.1007/s10151-016-1571-y

20. Garg P. Transanal opening of intersphincteric space (TROPIS) - A new procedure to treat high complex anal fistula. Int J Surg. (2017) 40:130-4. doi: 10.1016/j.ijsu.2017.02.095

21. Ozturk A, Atalay T, Cipe G, Luleci N. Ozone treatment for chronic anal fistula: it is not promising. Indian J Surg. (2017) 79:308-11. doi: 10.1007/s12262-016-1475-0

22. Stroumza N, Fuzco G, Laporte J, Nail Barthelemy R, Houry S, Atlan M. Surgical treatment of trans-sphincteric anal fistulas with the Fat GRAFT technique: a minimally invasive procedure. Colorectal Dis. (2017) 19:e316-e9. doi: $10.1111 /$ codi.13782

23. Kang WH, Yang HK, Chang HJ, Ko YT, Yoo BE, Lim CH, et al. High ligation of the anal fistula tract by lateral approach: a prospective cohort study on a modification of the ligation of the intersphincteric fistula tract (LIFT) technique. Int J Surg. (2018) 60:9-14. doi: 10.1016/j.ijsu.2018.08.008

24. Abdelnaby M, Emile S, El-Said M, Abdallah E, AbdelMawla A. Drained mucosal advancement flap versus rerouting Seton around the internal anal sphincter in treatment of high trans-sphincteric anal fistula: a randomized trial. Int J Surg. (2019) 72:198-203. doi: 10.1016/j.ijsu.2019.11.008

25. de la Portilla F, Muñoz-Cruzado MVD, Maestre MV, García-Cabrera AM, Reyes ML, Vázquez-Monchul JM, et al. Platelet-rich plasma (PRP) versus fibrin glue in cryptogenic fistula-in-ano: a phase III single-center, randomized, double-blind trial. Int J Colorectal Dis. (2019) 34:1113-9. doi: 10.1007/s00384-019-03290-6

26. Iqbal A, Ahmed T, Khan I, Perveen S, Khan MI. Outcome of use of $1 \%$ silver nitrate in patients with low lying perianal fistula. J Ayub Med Coll Abbottabad. (2019) 31:355-8.

27. Mascagni D, Pironi D, Grimaldi G, Romani AM, La Torre G, Eberspacher C, et al. OTSC ${ }^{\circledR}$ proctology vs. fistulectomy and primary sphincter reconstruction as a treatment for low trans-sphincteric anal fistula in a randomized controlled pilot trial. Minerva Chir. (2019) 74:1-6. doi: 10.23736/S0026-4733.18.07617-4

28. Omar W, Alqasaby A, Abdelnaby M, Youssef M, Shalaby M, Anwar AbdelRazik M, et al. Drainage Seton versus external anal sphincter-sparing Seton after rerouting of the fistula tract in the treatment of complex anal 
fistula: a randomized controlled trial. Dis Colon Rectum. (2019) 62:980-7. doi: 10.1097/DCR.0000000000001416

29. Arroyo A, Sánchez-Guillén L, Parra P. A., García-Catal,á, L., Peña-Ros, E., Ferrer-Márquez, M., et al. Photodynamic therapy for the treatment of complex anal fistula lasers. Surg Med. (2020) 52:503-8. doi: 10.1002/lsm.23162

30. Laureti S, Gionchetti P, Cappelli A, Vittori L, Contedini F, Rizzello F, et al. Refractory complex Crohn's perianal fistulas: a role for autologous microfragmented adipose tissue injection. Inflamm Bowel Dis. (2020) 26:32130. doi: 10.1093/ibd/izz051

31. Yan J, Ma L. Clinical effect of tunnel-like fistulectomy plus draining Seton combined with incision of internal opening of anal fistula (TFSIA) in the treatment of high trans-sphincteric anal fistula. Med Sci Monit. (2020) 26:e918228. doi: 10.12659/MSM.918228

32. Marinello F, Kraft M, Ridaura N, Vallribera F, Espín E. Treatment of fistula-inano with OTSC $\left({ }^{\circledR}\right)$ proctology clip device: short-term results. Cir Esp. (2018) 96:369-74. doi: 10.1016/j.cireng.2018.02.015

33. Seyfried S, Bussen D, Joos A, Galata C, Weiss C, Herold A. Fistulectomy with primary sphincter reconstruction. Int J Colorectal Dis. (2018) 33:911-8. doi: 10.1007/s00384-018-3042-6

34. Litta F, Parello A, De Simone V, Grossi U, Orefice R, Ratto C. Fistulotomy and primary sphincteroplasty for anal fistula: long-term data on continence and patient satisfaction. Tech Coloproctol. (2019) 23:993-1001. doi: 10.1007/s10151-019-02093-9

35. Zhao B, Wang Z, Han J, Zheng Y, Cui J, Yu S. Long-term outcomes of ligation of the inter-sphincteric fistula tract plus bioprosthetic anal fistula plug (LIFTPlug) in the treatment of trans-sphincteric perianal fistula. Med Sci Monit. (2019) 25:1350-4. doi: 10.12659/MSM.914925

36. De Hous, N., Van den Broeck, T., and de Gheldere, C. (2020). Fistulectomy and primary sphincteroplasty (FIPS) to prevent keyhole deformity in simple anal fistula: a single-center retrospective cohort study. Acta Chir Belg. 1-6. doi: 10.1080/00015458.2020.1753151

37. Zwiep TM, Gilbert R, Boushey RP, Schmid S, Moloo H, Raiche I, et al. Comparison of ligation of the intersphincteric fistula tract and BioLIFT for the treatment of transsphincteric anal fistula: a retrospective analysis. Dis Colon Rectum. (2020) 63:365-70. doi: 10.1097/DCR.0000000000001573

38. Bobkiewicz A, Krokowicz Ł, Borejsza-Wysocki M, Banasiewicz T. A novel model of acellular dermal matrix plug for anal fistula treatment. Report of a case and surgical consideration based on first utility in Poland. Pol Przegl Chir. (2017) 89:52-5. doi: 10.5604/01.3001.0010.3912

39. Takesue Y, Ohge H, Yokoyama T, Murakami Y, Imamura Y, Sueda T. Longterm results of seton drainage on complex anal fistulae in patients with Crohn's disease. J Gastroenterol. (2002) 37:912-5. doi: 10.1007/s005350200153

40. Eitan A, Koliada M, Bickel A. The use of the loose seton technique as a definitive treatment for recurrent and persistent high trans-sphincteric anal fistulas: a long-term outcome. J Gastrointest Surg. (2009) 13:1116-9. doi: 10.1007/s11605-009-0826-6

41. Mann CV, Clifton MA. Re-routing of the track for the treatment of high anal and anorectal fistulae. Br J Surg. (1985) 72:134-7. doi: 10.1002/bjs.1800720222
42. Rojanasakul A, Pattanaarun J, Sahakitrungruang C, Tantiphlachiva K. Total anal sphincter saving technique for fistula-in-ano; the ligation of intersphincteric fistula tract. J Med Assoc Thai. (2007) 90:581-6.

43. van Onkelen RS, Gosselink MP, Schouten WR. Ligation of the intersphincteric fistula tract in low transsphincteric fistulae: a new technique to avoid fistulotomy. Colorectal Dis. (2013) 15:587-91. doi: 10.1111/codi.12030

44. Lehmann JP, Graf W. Efficacy of LIFT for recurrent anal fistula. Colorectal Dis. (2013) 15:592-5. doi: 10.1111/codi.12104

45. van Onkelen RS, Gosselink MP, Schouten WR. Is it possible to improve the outcome of transanal advancement flap repair for high transsphincteric fistulas by additional ligation of the intersphincteric fistula tract? Dis Colon Rectum. (2012) 55:163-6. doi: 10.1097/DCR.0b013e31823c0f74

46. Emile SH, Khan SM, Adejumo A, Koroye O. Ligation of intersphincteric fistula tract (LIFT) in treatment of anal fistula: an updated systematic review, meta-analysis, and meta-regression of the predictors of failure. Surgery. (2020) 167:484-92. doi: 10.1016/j.surg.2019.09.012

47. Liu WY, Aboulian A, Kaji AH, Kumar RR. Long-term results of ligation of intersphincteric fistula tract (LIFT) for fistula-in-ano. Dis Colon Rectum. (2013) 56:343-7. doi: 10.1097/DCR.0b013e318278164c

48. Tan KK, Tan IJ, Lim FS, Koh DC, Tsang CB. The anatomy of failures following the ligation of intersphincteric tract technique for anal fistula: a review of 93 patients over 4 years. Dis Colon Rectum. (2011) 54:1368-72. doi: 10.1097/DCR.0b013e31822bb55e

49. Wright M, Thorson A, Blatchford G, Shashidharan M, Beaty J, Bertelson N, et al. What happens after a failed LIFT for anal fistula? Am J Surg. (2017) 214:1210-3. doi: 10.1016/j.amjsurg.2017.08.042

50. Prosst RL, Herold A, Joos AK, Bussen D, Wehrmann M, Gottwald T, et al. The anal fistula claw: the OTSC clip for anal fistula closure. Colorectal Dis. (2012) 14:1112-7. doi: 10.1111/j.1463-1318.2011.02902.x

51. Dango S, Antonakis F, Schrader D, Radzikhovskiy A, Ghadimi MB, Hesterberg R. Long-term efficacy and safety of a nitinol closure clip system for anal fistula treatment. Minim Invasive Ther Allied Technol. (2017) 26:227-31. doi: 10.1080/13645706.2017.1282521

52. Parkash S, Lakshmiratan V, Gajendran V. Fistula-in-ano: treatment by fistulectomy, primary closure and reconstitution. Aust N Z J Surg. (1985) 55:23-7. doi: 10.1111/j.1445-2197.1985.tb00849.x

Conflict of Interest: The authors declare that the research was conducted in the absence of any commercial or financial relationships that could be construed as a potential conflict of interest.

Copyright $(0) 2021 \mathrm{Ji}$, Zhang, Xu, Wei, Weng and Jiang. This is an open-access article distributed under the terms of the Creative Commons Attribution License (CC BY). The use, distribution or reproduction in other forums is permitted, provided the original author(s) and the copyright owner(s) are credited and that the original publication in this journal is cited, in accordance with accepted academic practice. No use, distribution or reproduction is permitted which does not comply with these terms. 